\title{
APLIKASI PENENTUAN DOSEN PENGUJI SKRIPSI MENGGUNAKAN METODE TF-IDF DAN VECTOR SPACE MODEL
}

\author{
Riki Ruli A. Siregar ${ }^{1}$, Fera Amelia Sinaga ${ }^{2}$, Rakhmat Arianto $^{3}$ \\ Program Studi Sarjana Teknik Informatika, Sekolah Tinggi Teknik PLN Jakarta \\ Jalan Lingkar Luar Barat Menara PLN Cengkareng, Jakarta Barat 11750 \\ e-mail : riki.ruli@sttpln.ac.id ${ }^{1}$, ameliafera@gmail.com ${ }^{2}$, arianto@sttpln.ac.id $^{3}$
}

\begin{abstract}
Abstrak
Pada Sekolah Tinggi Teknik PLN (STT-PLN) penentuan dosen penguji tugas akhir atau skripsi merupakan tugas dari sekretaris jurusan. Penelitian ini bertujuan untuk memberikan alternative untuk menentukan dosen penguji skripsi. Metode yang di terapkan untuk membangun system ini adalah text mining, TF-IDF dan Vector Space Model (VSM). Text mining untuk melakukan processing data, dimana data yang akan diproses adalah judul dan abstrak skripsi, sedangkan VSM untuk melakukan pengklasifikasian kompetensi, penelitian ini dapat merekomendasikan tiga dosen untuk menjadi dosen penguji skripsi berdasarkan kecocokan antara judul dan abstrak dengan klasifikasi Pada penelitian ini, penulis menggunakan Model pengembangan perangkat lunak CRISP-DM. Adapun fase yang dimiliki oleh CRISP-DM adalah fase pemahaman bisnis, fase pemahanman data, fase pengolahan data, fase permodelan, fase evaluasi dan fase penyebaran. Hasil dari penelitian ini memiliki akurasi 93,22\%.
\end{abstract}

Kata Kunci : Text mining, Vector Space Model, TF-IDF, klasifikasi, CRISP-DM.

\begin{abstract}
At the Technical College of PLN (STT-PLN), the determination of the lecturer of the final project or thesis is the task of the secretary of the department. This study aims to provide an alternative to determine thesis examiners lecturer. The method applied to build this system is text mining, TF-IDF and Vector Space Model (VSM). Text mining to perform data processing, where the data to be processed is the title and abstract of the thesis, while the VSM to perform the classification of competence, this study can recommend three lecturers to be a thesis examiner lecturer based on the fit between title and abstract by classification In this study, CRISP-DM software development Model. The phases of CRISP-DM are the business understanding phase, the data holding phase, the data processing phase, the Modeling phase, the evaluation phase and the deployment phase. The results of this study have an accuracy of $93,22 \%$.
\end{abstract}

Keywords : Text mining, Vector Space Model, TF-IDF, Clasification, CRISP-DM

\section{PENDAHULUAN}

Tugas akhir Skripsi merupakan perwujudan kualitas akademik mahasiswa dan sebagai penelitian syarat kelulusan. Dalam pengujian skripsi, penentuan dosen penguji merupakan hal yang penting, idealnya dosen penguji memiliki kompetensi yang sesuai dengan topik skripsi yang diteliti oleh mahasiswa agar didapat hasil pengujian yang maksimal. 
Dalam kasus ini peneliti mengambil tempat penelitian di Teknik Informatika STT-PLN, dimana proses pemilihan dosen penguji dipilih secara langsung oleh Sekretaris jurusan dengan di data pada aplikasi Microsoft Excel. Tidak adanya sistem yang digunakan menjadikan tugas sekretaris jurusan dalam menentukan dosen penguji yang sesuai antara judul atau tema tugas akhir dengan konsentrasi dosen penguji menjadi kurang akurat dan membutuhkan waktu proses. Dalam proses pelaksanaan pengujian atau sidang skripsi terdapat 3 (tiga) orang dosen penguji yang terdiri dari ketua penguji, sekretaris penguji dan penguji.

Syarat utama kompetensi dosen penguji yang sesuai dengan topik yang diangkat dalam skripsi, pada penelitian memberikan alternatif keputusan dalam menentukan dosen penguji skripsi yang akan di ujikan memiliki kesesuaian terhadap kompetensi. Penerapan text mining dapat digunakan untuk menganalisa data yang diperoleh dari judul dan abstrak skripsi mahasiswa. Untuk menerapkan text mining, dibutuhkan skripsi mahasiswa yang sebelumnya, sehingga dapat melihat pola-pola data yang terdahulu untuk dijadikan sebuah pengetahuan baru. Penerapan algoritma TF-IDF (Term Frequency-Inverse Document Frequency) dan VSM (Vector Space Model) yang dapat digunakan untuk mengklasifikasikan dosen penguji yang sesuai antara topik skripsi dengan kompetensi dosen, yang dilakukan dengan ekstraksi teks pada dokumen. Penelitian sebelumnya yang dilakukan sebelumnya koordinator tugas akhir dalam menentukan dosen pembimbing dan penguji skripsi [1]. Hasil penelitian membantu koordinator tugas akhir dalam menentukan dosen pembimbing dan penguji skripsi. Metode-metode yang digunakan untuk membangun sistem ini adalah Text Mining, $k$-Nearest Neighbor (k-NN), dan Simple Additive Weighting (SAW).

\section{KAJIAN PUSTAKA}

Penelitian yang berjudul "Analysis of Vector Space Model in Information Retrieval" [2], Menyajikan pendekatan yang berbeda dari model ruang vektor untuk menghitung nilai kesamaan hit dari mesin pencari dan yang lebih penting lagi, dirasakan bahwa penyelidikan ini akan menghasilkan pemahaman yang lebih jelas mengenai masalah dan masalah dalam menggunakan model ruang vektor dalam informasi. Pada penelitian ini menganalisis tiga pendekatan model ruang vektor untuk query uji coba. Nilai kemiripan dihitung dengan menggunakan tiga pendekatan model ruang vektor. Setelah mempertimbangkan persyaratan pembobotan dalam pengumpulan dokumen, kita dapat menghitung nilai kesamaan antara kueri dan dokumen. Peringkat dokumen tergantung pada nilai kesamaan nilai yang dihitung dengan pendekatan yang berbeda. Peringkat dokumen tergantung pada nilai kesamaan nilai yang dihitung dengan pendekatan yang berbeda Dari VSM. Nilai kesamaan yang dihitung dengan model penghitung waktu bagus untuk dokumen panjang namun model TF-IDF dan normalisasi memberikan hasil yang lebih baik. Model normalisasi juga menggunakan skema bobot global dan memberikan hasil yang sama untuk dokumen panjang dibandingkan dengan model TF-IDF. Jadi ketiga pendekatan model ruang vektor mungkin mendukung dokumen panjang yang berisi lebih banyak tampilan istilah kueri.

Penelitian selanjutnya, berjudul "A Text Categorization Method using Extended Vector Space Model by Frequent Term Sets "[3]. Penelitian ini membahas tentang pengkategorian teks, Sebuah batasan baru AD-Sup diperkenalkan untuk mengekstrak fitur diskriminatif dari rangkaian istilah yang sering digunakan untuk tugas klasifikasi. Hasil klasifikasi pada korpus Reuters-21578 dan WebKB menunjukkan bahwa kendala AD-Sup efektif untuk mengekstrak fitur yang berguna dan strategi kombinasi efektif untuk membangun ruang fitur yang lebih baik dan memperbaiki klasifikasi. 
Pertambangan web mencakup tiga bagian yaitu penambangan struktur web, penambangan konten web, penambangan penggunaan web. Tujuan dari proses analisis lanjutan ini adalah untuk mengekstrak informasi dari kumpulan data dan mengubahnya menjadi struktur yang mudah dimengerti untuk digunakan lebih jauh. Data mining terdiri dari tiga langkah dasar Ekstrak informasi, memuat informasi \& menampilkan informasi (out-put)[4]

\subsection{Text Mining}

Text mining merupakan salah satu bidang khusus dari data mining. Text mining dapat didefinisikan sebagai suatu proses menggali informasi dimana seseorang user berinteraksi dengan sekumpulan dokumen menggunakan tool analisis yang merupakan komponenkomponen dalam data mining [5]. Text mining digunakan untuk mengolah dokumen sebelum dilakukan proses similarity. Text mining merupakan proses ekstraksi pola (informasi dan pengetahuan yang berguna) dari sejumlah besar sumber data tak terstruktur. Text mining memiliki tujuan dan menggunakan proses yang sama dengan data mining, namun memiliki masukan yang berbeda.Masukan untuk Text mining adalah data yang tidak (atau kurang) terstruktur, seperti dokumen Word, PDF, kutipan teks, dll., sedangkan masukan untuk data mining adalah data yang terstruktur.

\subsection{Text Preprocessing}

Didalam proses Text mining terdapat proses Text Processing[6]. Preprocessing text merupakan tindakan menghilangkan karakter-karakter tertentu yang terkandung dalam dokumen, seperti koma, tanda petik dan lain-lain serta mengubah semua huruf kapital menjadi huruf kecil. Selain itu, dalam tahap text preprocessing ini dilakukan tokenization. Tokenization merupakan proses pengolahan token yang terdapat dalam rangkaian teks, sehingga dokumen akan dipecah-pecah menjadi term [7]. Text mining dalam prakteknya mencari pola-pola tertentu, mengasosiasikan suatu bagian teks dengan yang lain berdasarkan aturan-aturan tertentu, katakata yang dapat mewakili sehingga dapat dilakukan analisa keterhubungan antar satu dengan yang lain [5]. Berikut tahapan-tahapan proses didalam text mining:

a. Tokenizing

Tahap Tokenizing adalah tahap pemotongan tiap kata dalam kalimat atau parsing dengan menggunakan spasi sebagai delimiter yang akan menghasilkan token berupa kata. Pada tokenizing terdapat beberapa proses yang harus dilakukan yaitu merubah semua hruf besar menjadi kecil (text to lowercase). Proses selanjutnya adalah penguraian, proses penguraian yang dimaksud adalah membagi text menjadi kumpulan kata tanpa memperhatikan keterhubungan antara kata satu dengan kata lain serta peran dan posisinya pada kalimat.

b. Filtering

Tahap Filtering adalah tahap penyaringan kata yang didapat dari Tokenizing yang dianggap tidak penting atau tidak memiliki makna dalam proses Text mining yang disebut stopword. Stopword berisi katakata umum yang sering muncul dalam sebuah dokumen dalam jumlah banyak namun tidak memiliki kaitan dengan tema tertentu. Contoh stopwords adalah "yang", "di”, 'yang', dll.

c. Stemming

Tahap stemming adala tahap mengembalikan kata-kata yang diperoleh dari hasil Filtering ke bentuk dasarnya, menghilangkan imbuhan awal (prefix) dan imbuhan akhir (sufix) sehingga didapat kata dasar. 


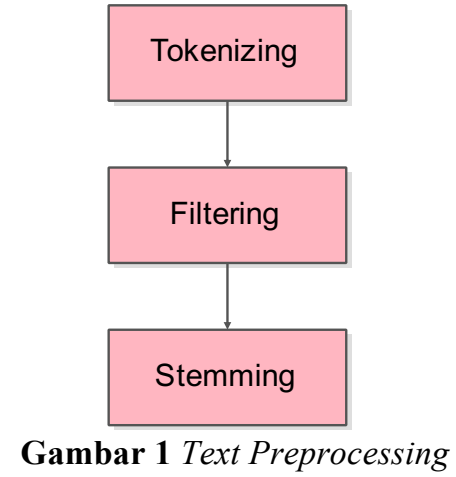

\subsection{Pembobotan Kata (Term Weighting)}

Pembobotan kata sangat berpengaruh dalam menentukan keiripan antara dukumen dengan query. Apabila bobot tiap kata dapat ditentukan dengan tepat, diharapkan haisl perhitungan kemiripan teks akan menghasilkan perangkingan dokumen yang baik. Keberhasilan dari model ruang vector ditentukan oleh skema pembobotan terhadap suatu term baik untuk cakupan local maupun global, dan faktor normalisasi [8]. Pembobotan local hanya berpedoman pada frekuensi munculnya term dalam satu dokumen dan tidak melihat kemunculan term tersebut di dalam dokumen lainnya. Faktor yang memegang peranan penting dalam pembobotan kata yaitu :

\section{Term Frequency (tf)}

Pendekatan dalam pembobotan local yang paling banyak diterapkan adalah term frequency (tf). Factor ini menyatakan banyaknya kemunculan suatu kata dalam suatu dokumen. Semakin sering suatu kata muncul dalam sebuah dokumen, berarti semakin penting kata tersebut. Ada empat cara yang bisa digunakan untuk mendapatkan nilai TF:

a. Raw Tf

Nilai Tf sebuah term dihitung berdasarkan kemunculan term tersebut dalam dokumen.

b. Logarithmic Tf

Dalam memperoleh nilai Tf, cara ini menggunakan fungsi logaritmik dalam matematika.

c. Binnary Tf

$$
\mathrm{TF}=1+\log (\mathrm{TF})
$$

Cara ini menghasilkan nilai Boolean berdasarkan kemunculan term pada dokumen tersebut. Akan bernilai 0 apabila term tidak ada pada sebuah dokumen, dan bernilai 1 apabila term tersebut ada dalam dokumen. Sehingga banyaknya kemunculan term pada dokumen tidak berpengaruh.

d. Augmented Tf

$$
\mathrm{TF}=0.5+0.5 \times \mathrm{TFmax}(\mathrm{TF})
$$

Nilai TF adalah jumlah kemunculan term pada sebuah dokumen. Nilai max(Tf) adalah jumlah kemunculan terbanyak term pada dokumen yang sama.

Perhitungan Tf yang akan digunakan dalam implementasi sistem temu kembali informasi pada sistem yang penulis bangun adalah Raw Tf.

\section{Inverse Dokumen Frequency (IDF)}

Metode TF-IDF (Term Frequency Inverse Document Frequency) merupakan suatu cara untuk memberikan bobot hubungan suatu kata (term) terhadap dokumen. Metode ini menggabungkan dua konsep untuk perhitungan bobot yaitu, frekuensi kemunculan sebuah kata didalam sebuah dokumen tertentu dan inverse frekuensi dokumen yang menggandung kata tersebut [9]. Formula yang digunakan pada term frequency (tf), terdapat yaitu nilai tf diberikan berdasarkan jumlah kemunculan suatu kata di dokumen. Idf dihitung dengan formula sebagai berikut : 
Dimana :

$$
I D F=\log \frac{\mathrm{D}}{\mathrm{Df}}
$$

IDF $=$ Invers dokumen frekuensi

$\mathrm{D}=$ Total Dokumen

Df $=$ Frequensi dokumen dari term

Log $=$ Untuk memperkecil pengaruhnya relative terhadap tf

Bobot term dihitung dengan menggunakan rumus :

$$
\mathrm{W}=\mathrm{tf} \mathrm{x} \text { idf }
$$

Dimana :

$\mathrm{W}=$ Bobot dokumen

$\mathrm{Tf}=$ Term frekuensi

Idf $=$ Invers dokumen frekuensi

\subsection{Vector Space Model}

Vector Space Model (VSM) sering digunakan untuk mempresentasikan sebuah dokumen dalam ruang vector. VSM merupakan model Information Retrieval yang mempresentasikan dokumen dan query sebagai vektor pada ruang multidimensi. Kesamaan suatu dokumen dengan query dapat diukur dengan vektor dokumen dan vektor query [7].

Karakteristik model ruang vector antara lain :

1. Model vector berdasarkan keyterm.

2. Model vector mendukung partial matching (sebagian sesuai) dan penentuan peringkat dokumen.

3. Prinsip dasar model vector adalah :

a. Dokumen direpresentasikan dengan menggunakan vector keyterm.

b. Ruang dimensi ditentukan oleh keyterms.

c. Query direpresentasikan dengan menggunakan vector keyterm.

d. Kesamaan dokumen keyterm dihitung berdasarkan jarak vector.

4. Model ruang vector memerlukan :
a. Bobot keyterm untuk vector dokumen.
b. Normalisasi keyterm untuk vector dokumen.
c. Normalisasi keyterm untuk vector query.
d. Perhitungan jarak untuk vector dokumen keyterm.

5. Kinerja model ruang vector :

a. Efisien.

b. Mudah dalam representasi.

c. Dapat diimplementasikan pada document matching dan partial matching.

Prosedur model ruang vector dapat dikelompokkan menjadi tiga tahap yaitu:

1. Pengindeksan dokumen.

2. Pembobotan indeks, untuk menghasilkan dokumen yang relevan.

3. Memberikan peringkat dokumen berdasarkan ukuran kesamaan (similarity measure).

Perhitungan kemiripan antara vektor dokumen dan vektor query dilihat dari sudut yang paling kecil. Sudut yang dibentuk oleh dua buah vektor dapat dihitung dengan melakukan inner product. Kemiripan antara vektor dokumen dan vektor query akan dihitung dengan pendekatan Cosine Similarity [8] Nilai relevansi (similarity) antara query dengan dokumen ke-j [9] adalah :

Dimana :

$$
\operatorname{Cos} \operatorname{Sim}(d j, q)=\frac{\vec{d}_{j} \cdot \vec{q}}{\left|\overrightarrow{d_{j}}\right| \cdot|\vec{q}|}-\frac{\sum_{i=1}^{t}\left(w_{i j} \cdot w_{i q}\right)}{\sqrt{\sum_{i=1}^{t} w_{i j}^{2} \cdot \sum_{i=1}^{t} w_{i q}{ }^{2}}}
$$

$\overrightarrow{d_{J}}=$ Bobot dokumen $\mathrm{j}$

$\vec{q}=$ Bobot query 


$$
\begin{aligned}
& \left|\overrightarrow{d_{j}}\right|=\text { Panjang bobot dokumen } \mathrm{j} \\
& |\vec{q}|=\text { Panjang bobot query } \\
& w_{i j}=\text { Bobot term i pada dokumen } \mathrm{j} \\
& w_{i q}=\text { Bobot term i pada query } \\
& \mathrm{T}=\text { Teks }
\end{aligned}
$$

\subsection{CRISP-DM}

Cross-Industry Standard Process for Data Mining (CRISP-DM) merupakan suatu standar yang telah dikembangkan pada tahun 1996 yang ditujukan untuk melakukan proses analisis dari suatu industri sebagai strategi pemecahan masalah dari bisnis atau unit penelitian.

Terdapat enam fase pada CRISP-DM yaitu sebagai berikut :

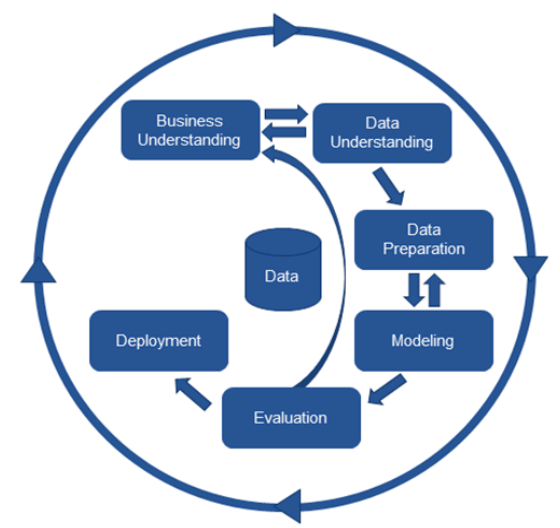

Gambar 2 Proses CRISP-DM (Sumber: http://www.kdnuggets.com)

a. Fase Pemahaman Bisnis (Business Understanding Phase)

b. Fase Pemahaman Data (Data Understanding Phase)

c. Fase Pengolahan Data (Data Preparation Phase)

d. Fase Pemodelan (Modeling Phase)

e. Fase Evaluasi (Evaluation Phase)

f. Fase Penyebaran (Deployment Phase)

\section{METODE PENELITIAN}

\subsection{Analisa Kebutuhan}

Analisa kebutuhan merupakan tahapan awal penelitian. Pada tahap ini dilakukan analisa kebutuhan suatu data menggunakan metode CRISP-DM, dimana data akan diproses dengan melakukan beberapa tahapan seperti berikut:

\subsubsection{Business Understanding Phase (Fase Pemahaman Bisnis)}

Pada tahap ini akan di lakukan penentuan tujuan penelitian dan kebutuhan secara detail dalam lingkup bisnis atau unit penelitian secara keseluruhan. Menerjemahkan tujuan dan batasan menjadi formula dari permasalahan, pada penelitian ini memiliki tujuan untuk menciptakan alternative penentuan dosen penguji skripsi secara otomatis dan mengimplementasikan metode text mining yaitu TF-IDF dan VSM dalam menentukan dosen penguji skripsi yang sesuai antara kompetensi dosen dengan klasifikasi skripsi mahasiswa, dimana klasifikasi skripsi tersebut terdiri dari tiga kategori yaitu, sistem informasi (si), jaringan dan embedded. Penelitian ini dilaksanakan di Jurusan Teknik Informatika STT-PLN, waktu penelitian serta perancangan mulai pada bulan Maret 2017 hingga selesai. 


\subsubsection{Data Understanding Phase (Fase Pemahaman Data)}

Pada tahap ini adalah tahap pengumpulan data, data diperoleh dari perpustakaan STTPLN dan jurusan Teknik Informatika STT-PLN. Pada penelitian ini data yang digunakan adalah 59 data dari skripsi mahawiswa STT-PLN. Data yang diambil dari data skripsi adalah judul dan abstrak, yang mana judul dan abstrak tersebut akan diolah kembali agar menghasilkan suatu bobot tertentu. Data skripsi yang diambil merupakan data dari tahun 2013-2015, data dosen penguji dan mahasiswa juga dibutuhkan dalam proses penentuan ini, data dosen penguji diperlukan untuk menentukan dosen penguji yang tepat atau sesuai dengan klasifikasi skripsi

a. Data skripsi yang akan digunakan

Tabel 1 Data set skripsi $2013-2015$

\begin{tabular}{|c|c|c|c|c|c|c|}
\hline No & NIM & Nama & Pembimbing 1 & Pembimbing 2 & Judul & Abstrak \\
\hline 1 & $\begin{array}{l}20103 \\
1155\end{array}$ & $\begin{array}{l}\text { Prayudi } \\
\text { wiranata }\end{array}$ & Indrianto & $\begin{array}{l}\text { Puji Catur } \\
\text { Siswiprapt } \\
\text { ini }\end{array}$ & \begin{tabular}{|l|} 
Perancangan \\
Model Robot \\
Pemindah \\
Barang berupa \\
Kotak (Box) \\
yang Berjalan \\
Mengikuti Line \\
Followers \\
dengan \\
Menggunakan \\
Arduino
\end{tabular} & $\begin{array}{l}\text { Pada perancangan robot yang berfungsi sebagai mobil } \\
\text { otomatis pemindah barang berbasis mikrokontroler Arduino } \\
\text { uno.Perancangan geraknya dilengkapi } 2 \text { motor DC yang } \\
\text { dapat berputar secara differential. Putaran arah motor yang } \\
\text { dirancang pada robot menggunakan driver motor DC. Untuk } \\
\text { gerak maju, belok, ataupun mundur digunakan } 2 \text { motor DC } \\
\text { di sisi kiri dan kanannya. Robot ini dilengkapi sensor LDR } \\
\text { (light depedent resistor) dan } 2 \text { Lampu LED sebagai penerang } \\
\text { Jalur (Line) Sensor ini mempunyai } 3 \text { fungsi, yakni sebagai } \\
\text { pendeteksi jalur lintasan pergerakan, pendeteksi tempat } \\
\text { tujuan persediaan barang dan pendeteksi jenis barang yang } \\
\text { akan dipindahkan. Robot hanya dapat bergerak pada lintasan } \\
\text { acuan berupa garis hitam dengan lebar } 1.5 \text { cm. Keseluruhan } \\
\text { sub sistem yang dibangun pada robot dikendalikan oleh } \\
\text { mikrokontroler, sehingga secara operasionalnya robot dapat } \\
\text { optimal mendeteksi adanya tempat persediaan barang dan } \\
\text { dapat memindahkannya ke tempat yang dituju sesuai dengan } \\
\text { program. Instruksi perintah input pada mikrokontroler } \\
\text { dengan menggunakan aplikasi Arduino Uno IDE Versi } 1.5 .8 \text {. } \\
\text { Dengan tegangan } 5 \text { volt pada penggerak jalan robot didapat } \\
\text { kecepatan rata-rata dan stabil. Untuk robot yang berbelok } \\
\text { stabil pada jalur lintasan. Tingkat keberhasilan robot } \\
\text { memindahkan barang sesuai tujuan mencapai 95\%. }\end{array}$ \\
\hline 2 & $\begin{array}{l}20113 \\
1042\end{array}$ & $\begin{array}{c}\text { Desy } \\
\text { Aisyah }\end{array}$ & $\begin{array}{l}\text { Riki Ruli } \\
\text { Affandi } \\
\text { Siregar }\end{array}$ & $\begin{array}{l}\text { Efy } \\
\text { Yosrita }\end{array}$ & $\begin{array}{l}\text { Rancang } \\
\text { Bangun Alat } \\
\text { Peraga } \\
\text { Modul } \\
\text { Praktikum } \\
\text { Embedded } \\
\text { Sistem } \\
\text { Menggunak } \\
\text { an } \\
\text { Raspberry } \\
\mathrm{Pi}\end{array}$ & $\begin{array}{l}\text { Penelitian ini bertujuan untuk membuat suatu alat peraga } \\
\text { beserta modul praktikum embedded system untuk } \\
\text { menunjang pelaksanaan praktikum embedded system di } \\
\text { sekolah tinggi teknik PLN Jakarta menggunakan modul } \\
\text { praktikum berbasis open source. Dalam penelitian } \\
\text { pembuatan modul embedded system menggunakan raspberry } \\
\text { pi dan mikrokontroler arduino menggunakan metode } \\
\text { prototyping. Penelitian dimulai dengan identifikasi masalah, } \\
\text { pengumpulan data, dan analisis, kemudian perancangan } \\
\text { perangkat lunak dan perangkat keras. Implementasi yaitu } \\
\text { melakukan uji coba langsung kepada praktikan. Penelitian } \\
\text { ini menghasilkan suatu modul praktikum embedded system } \\
\text { yang dapat digunakan untuk menunjang pelaksanaan } \\
\text { praktikum embedded system. Modul praktikum yang } \\
\text { dihasilkan ini diharapkan dapat diimplementasikan dengan } \\
\text { baik dan benar. }\end{array}$ \\
\hline
\end{tabular}

b. Data Dosen penguji

Data Penguji adalah nama-nama dosen yang dapat menjadi penguji di Teknik Informatika STT-PLN, dosen penguji terbagi menjadi tiga bagian yaitu, ketua penguji, sekretaris dan anggota penguji. Dosen yang dapat menjadi ketua penguji adalah dosen dengan jabatan lektor kepala dan lektor, untuk sekretaris, dosen yang dapat menjadi sekretaris adalah dosen dengan jabatan asisten ahli, sedangkan yang dosen yang digunakan dapat dilihat pada tabel 2 dibawah ini: 
Computatio: Journal of Computer Science and Information Systems, volume 1, no 2, Oktober 2017

Tabel 2 Data ketersediaan dosen penguji

\begin{tabular}{|r|l|l|l|l|}
\hline NO & \multicolumn{1}{|c|}{ NIM } & \multicolumn{1}{|c|}{ NAMA } & \multicolumn{1}{|c|}{ JABATAN } & KOMPETENSI \\
\hline $\mathbf{1}$ & 0326058501 & Yessy Fitriani & Asisten_Ahli & jaringan \\
\hline $\mathbf{2}$ & 0315035301 & Wisnu Hendro martono & Asisten_Ahli & embedded \\
\hline $\mathbf{3}$ & 0331057901 & Rakhmadi Irfansyah Putra & Asisten_Ahli & jaringan \\
\hline $\mathbf{4}$ & 0325076202 & Dwina Kuswardani & Asisten_Ahli & si \\
\hline $\mathbf{5}$ & 0815058202 & Abdul Haris & Asisten_Ahli & si \\
\hline $\mathbf{6}$ & 0303117101 & Yasni Djamain & Lektor_ & si \\
\hline $\mathbf{7}$ & 0315097901 & Rizqia Cahyaningtyas & Lektor & si \\
\hline $\mathbf{8}$ & 0301027703 & Puji Catur Siswipraptini & Lektor & si \\
\hline $\mathbf{9}$ & 0314127401 & Efy Yosrita & Lektor & si \\
\hline $\mathbf{1 0}$ & 0329098303 & Dian Hartanti & Lektor & si \\
\hline $\mathbf{1 1}$ & 0301097501 & Indrianto & Lektor & embedded \\
\hline $\mathbf{1 2}$ & 0307117301 & Iriansyah & Lektor & embedded \\
\hline $\mathbf{1 3}$ & 0320047601 & Sely karmila & Lektor & si \\
\hline $\mathbf{1 4}$ & 0328087401 & Dewi Arianti Wulandari & Lektor & si \\
\hline $\mathbf{1 5}$ & 0313107601 & Yessy Asri & lektor_kepala & si \\
\hline $\mathbf{1 6}$ & 0318057601 & Meilia Nur Indah Susanti & lektor_kepala & si \\
\hline $\mathbf{1 7}$ & 0320086401 & Darma Rusjdi & lektor_kepala & embedded \\
\hline $\mathbf{1 8}$ & 0316067501 & Luqman & lektor_kepala & embedded \\
\hline $\mathbf{1 9}$ & 0415078201 & Rahma Farah Ningrum & Asisten_Ahli & si \\
\hline $\mathbf{2 0}$ & 0301057706 & Riki Ruli Affandi Siregar & Asisten_Ahli & embedded \\
\hline $\mathbf{2 1}$ & 0310068702 & Abdurrasyid & tenaga_pengajar & si \\
\hline $\mathbf{2 2}$ & 0316088002 & Herman Bedi Agtriadi & tenaga_pengajar & embedded \\
\hline $\mathbf{2 3}$ & 0308018702 & Rakhmat Arianto & tenaga_pengajar & si \\
\hline $\mathbf{2 4}$ & 0326118901 & Dine Tiara Kusuma & tenaga_pengajar & si \\
\hline $\mathbf{2 5}$ & 0328029002 & M. Yoga Distra Sudirman & tenaga_pengajar & jaringan \\
\hline $\mathbf{2 6}$ & 0413057701 & Hendra Djatnika & tenaga_pengajar & si \\
\hline $\mathbf{2 7}$ & 0328127302 & Rosida Nur Aziza & tenaga_pengajar & embedded \\
\hline $\mathbf{2 8}$ & 0313058902 & Karina Djunaidi & tenaga_pengajar & si \\
\hline
\end{tabular}

c. Data Mahasiswa

Data mahasiswa dibawah ini adalah data mahasiswa yang digunakan dalam penelitian ini.

Tabel 3 Sample Data Mahasiswa

\begin{tabular}{|r|l|l|l|l|}
\hline NO & \multicolumn{1}{|c|}{ NIM } & \multicolumn{1}{|c|}{ NAMA } & \multicolumn{1}{c|}{ PEMBIMBING 1 } & \multicolumn{1}{c|}{ PEMBIMBING 2 } \\
\hline 1 & 201031155 & Prayudi wiranata & Indrianto & Puji Catur Siswipraptini \\
\hline 2 & 201031066 & Satria siswanto nugroho & Yasni Djamain & Rahma Farah Ningrum \\
\hline 3 & 200931006 & Ardi yanuari akbar & Wisnu Hendro Martono & Sely karmila \\
\hline 4 & 200831025 & Jefri Toding Lamba & Puji Catur Siswipraptini & Rakhmat Arianto \\
\hline 5 & 201131042 & Desy Aisyah & Riki Ruli Affandi Siregar & Iriansyah \\
\hline 6 & 201131133 & Arjumiati & Dwina Kuswardani & Rahma Farah Ningrum \\
\hline 7 & 201231006 & Lidya intan & Efy Yosrita & Meilia Nur Indah Susanti \\
\hline 8 & 201231008 & Anita Andiani & Indrianto & Iriansyah \\
\hline 9 & 201231009 & Rifaldi Andrian & Yasni Djamain & Wisnu Hendro martono \\
\hline 10 & 201231012 & Arbu Marna & Iriansyah & Rakhmat Arianto \\
\hline 11 & 201231014 & Nindy Navtalia Sihite & Rakhmat Arianto & Rahma Farah Ningrum \\
\hline 12 & 201231015 & Adithya Marhendra Kusuma & Iriansyah & Riki Ruli Affandi Siregar \\
\hline 13 & 201231016 & Elsa Aprianis M & Puji Catur Siswipraptini & Riki Ruli Affandi Siregar \\
\hline
\end{tabular}

\subsubsection{Data Preparation Phase (Fase Pengolahan Data)}

Pada tahap ini merupakan persiapan data awal untuk diimplementasikan pada sebuah perangkat permodelan atau Data Transformation, dari penelitian ini 59 data skripsi yang di dapat akan di proses dan dihasilkan jenis kategorinya yang nanti akan dicocokan dengan kompetensi dosen penguji. Dokumen skripsi akan diolah menggunakan metode text preprocessing. Text preprocessing merupakan Tahap proses awal terhadap dokumen skripsi untuk mempersiapkan dokumen menjadi dokumen yang akan diolah lebih lanjut. Tahapan yang dilakukan secara umum adalah tokenizing, filtering, stemming. 


\section{a. Tokenizing}

Pada proses tokenizing dilakukan pembacaan dokumen yang dimiliki dan memisahkan deretan kata didalam kalimat, paragraph atau dokumen menjadi token atau potongan kata tunggal. Tokenization dapat dilakukan dengan menghilangkan tanda baca dan memisahkannya per spasi. Tahapan ini juga menghilangkan karakter-karakter tertentu seperti tanda baca dan mengubah semua token ke bentuk huruf kecil (lower case). Alur pada tokenizing dapat dilihat dari flowchart dibawah ini

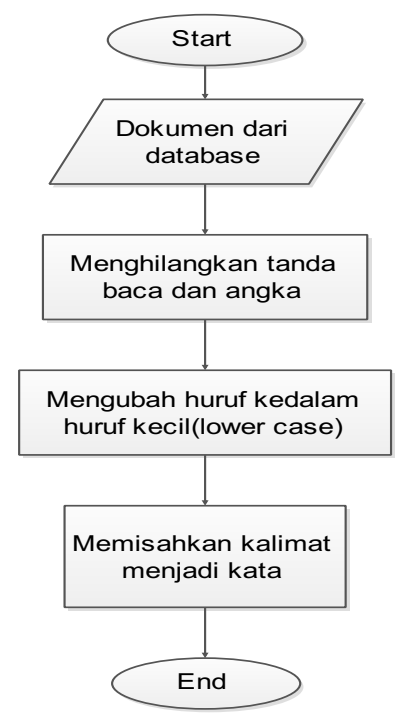

b. Filtering

Gambar 3 Flowchart Tokenizing

Pada tahapan ini dilakukan pengambilan kata-kata penting dari hasil tokenizing dengan membuang stopwords (kata-kata yang kurang penting). Stopword dapat berupa subjek atau kata penghubung. Filtering dilakukan dengan menentukan term mana yang akan digunakan untuk merepresentasikan dokumen sehingga dapat mendeskripsikan isi dokumen dan membedakan dokumen tersebut. Alur dari Filtering dapat dilihat pada flowchart dibawah ini:

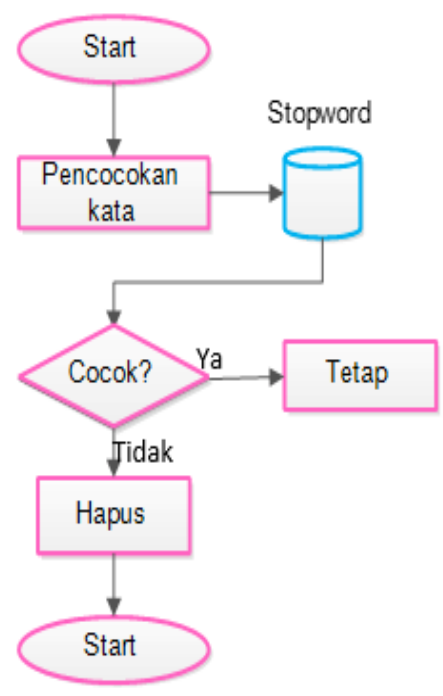

c. Stemming

Gambar 4 Diagram Alir Filtering

Stemming merupakan suatu proses yang terdapat dalam sistem IR yang mentransformasi kata-kata yang terdapat dalam suatu dokumen ke kata-kata akarnya (root word) dengan menggunakan aturan-aturan tertentu. Pada tahap ini akan dicari root kata dari tiap kata hasil Filtering. 


\subsubsection{Modelling Phase (Fase Permodelan)}

Pada tahap ini data yang telah dilakukan text preprocessing akan di proses ke tahap selanjutnya dengan beberapa permodelan. Permodelan ini dilakukan untuk mengoptimalkan hasil yang ingin dicapai. Metode yang digunakan dalam penelitian ini adalah TF-IDF dan VSM, Pada tahap ini merupakan tahap pembobotan dan pengklasifikasian data skripsi, dokumen yang sudah di proses dengan text preprocessing akan diberi bobot dan diliat jarak kemiripannya. Didalam penulisan ini ada tiga kategori yaitu sistem informasi, embedded dan jaringan dimana keyword dalam klasifikasi tersebut sudah ditentukan oleh penulis terlebih dahulu. alur atau flowchart metode tersebut dapat dilihat dari gambar disamping ini:

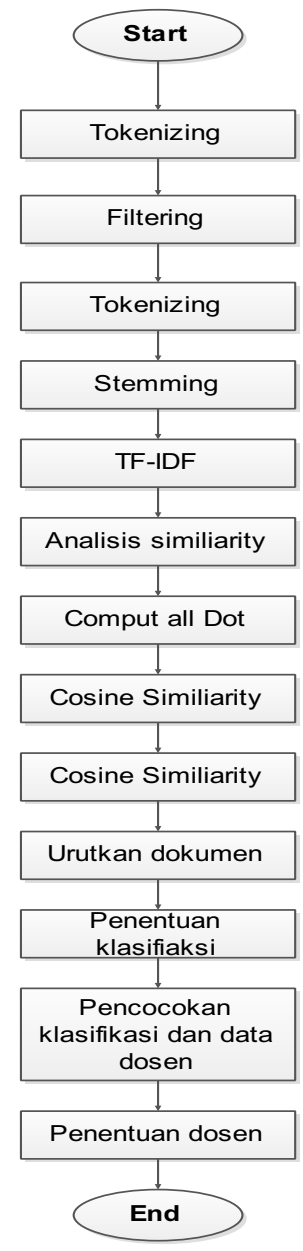

Gambar 5 Diagram Alir TF-IDF dan VSM

\subsubsection{Evaluation Phase (Fase Evaluasi)}

Fase evaluasi merupakan tahap untuk mengetahui apakah model yang di rancang telah sesuai atau belum dengan tujuan pada fase awal. Tujuan awal di dirancangnya model ini yaitu agar menghasilkan nilai akurasi yang tinggi, sehingga dapat membuktikan bahwa penelitian yang dilakukan telah berhasil. Pada penelitian ini dilakukan beberapa cara untuk melihat nilai akurasi yang dihasilkan. Peneliti menggunakan cara perbandingan antara sistem yang telah dibangun dengan klasifikasi penentuan skripsi yang telah dilakukan berdasarkan hasil wawancara. diperoleh nilai akurasi antara sistem dan hasil dari wawancara memiliki nilai yang sama yaitu sebesar 93,22\%. dengan tingkat error sebesar 6,78\%. Hasil penjelasan perhitungan dijelaskan pada bab pembahasan. Dengan hasil yang diperoleh sama, sehingga dapat dibuktikan bahwa aplikasi yang dibangun dapat digunakan karena menghasilkan nilai akurasi yang tinggi. 


\section{HASIL DAN PEMBAHASAN}

\subsection{Hasil Rancangan Antarmuka}

Rancang Bangun Penentuan Dosen Penguji Skripsi Dengan Menggunakan Metode TFIDF Dan Vector Space Model dapat digunakan oleh sekertaris jurusan, dosen dan mahasiswa. Secara garis besar, desain arsitektur Rancang Bangun Penentuan Dosen Penguji Skripsi dapat dilihat pada gambar dibawah ini:

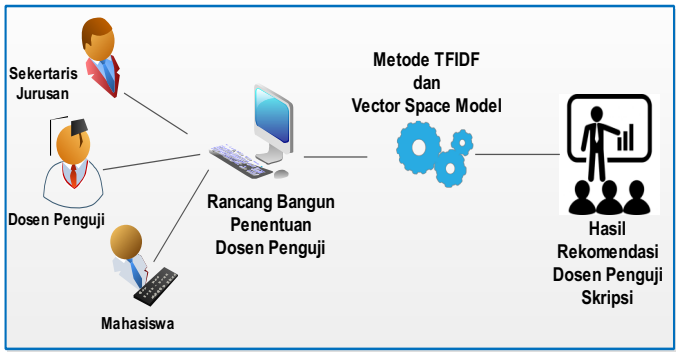

Gambar 6 Desain Arsitektur Penentuan Dosen Penguji

Gambar 6 menjelaskan desain arsitektur rancang bangun penentuan dosen penguji. Rancang bangun tersebut dapat diakses oleh tiga jenis user, yaitu: Sekertaris Jurusan sebagai admin, mahasiswa dan dosen. Setiap user memiliki hak akses tersendiri terhadap aplikasi. Metode TFIDF dan Vector Space Model di diimplementasikan kedalam rancang bangun untuk menentukan pilihan atau hasil rekomendasi dari dosen penguji yang sesuai antara kompetensi dosen dan topik skripsi. Berikut adalah gambaran dan rincian kegunaan aplikasi:

\section{Tampilan Login}

Saat aplikasi pertama kali dijalankan, user akan diminta untuk memasukkan username dan password hal ini digunakan untuk validasi apakah user terdaftar dalam database atau tidak. User yang dapat login adalah user yang telah terdaftar sebagai dosen dan mahasiswa mengikuti sidang skripsi. Dalam aplikasi ini terdapat tiga buah user yaitu sekertaris jurusan (sekjur), mahasiswa dan dosen, masing-masing akan memiliki menu yang berbeda. Interface halaman login dapat dilihat pada gambar dibawah ini:

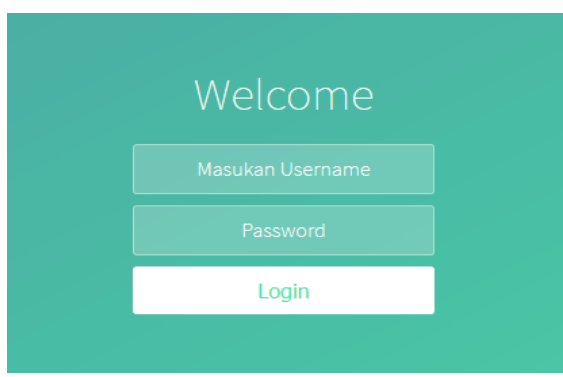

Gambar 7 Halaman Login

Setelah dilakukan validasi dan username dan password sesuai dengan data yang ada, maka user akan masuk ke halaman dan bisa mengakses menu yang ada didalamnya.

\section{Tampilan Menu Sekretaris Jurusan}

a. Halaman Utama

Pada halaman utama menampilkan empat buah icon, dimana jika pada icon di click maka user akan masuk kedalam tampilan form yang iconnya telah dipilih. 
Computatio: Journal of Computer Science and Information Systems, volume 1, no 2, Oktober 2017

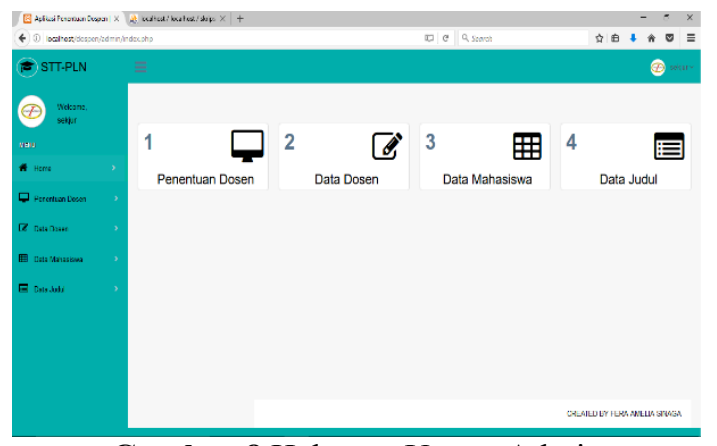

Gambar 8 Halaman Utama Admin

b. Halaman Data Dosen

Pada halaman data dosen, terdapat tabel Informasi data dosen seperti nim, nama, nomor hp, jabatan, kompetensi dan action. Sekertaris jurusan memiliki hak untuk menambah, mengedit dan menghapus data dosen. Pada halaman dosen ini dilengkapi juga fitur import kedalam csv dan print.

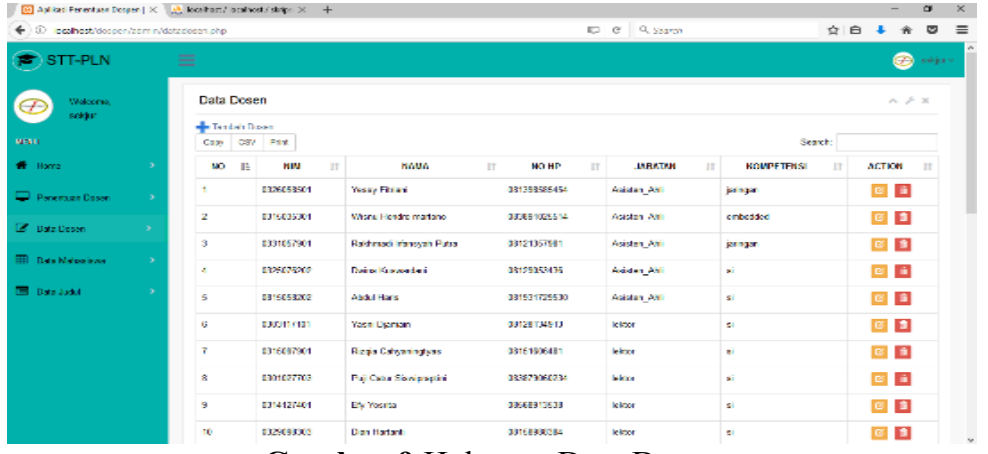

Gambar 9 Halaman Data Dosen

c. Halaman Data Mahasiswa

Pada halaman data mahasiswa, terdapat tabel Informasi data mahasiswa seperti nim, nama, pembimbing 1 dan pembimbing 2. Sekertaris jurusan memiliki hak untuk menambah, mengedit dan menghapus data mahasiswa. Pada halaman dosen ini dilengkapi juga fitur import kedalam csv dan print.

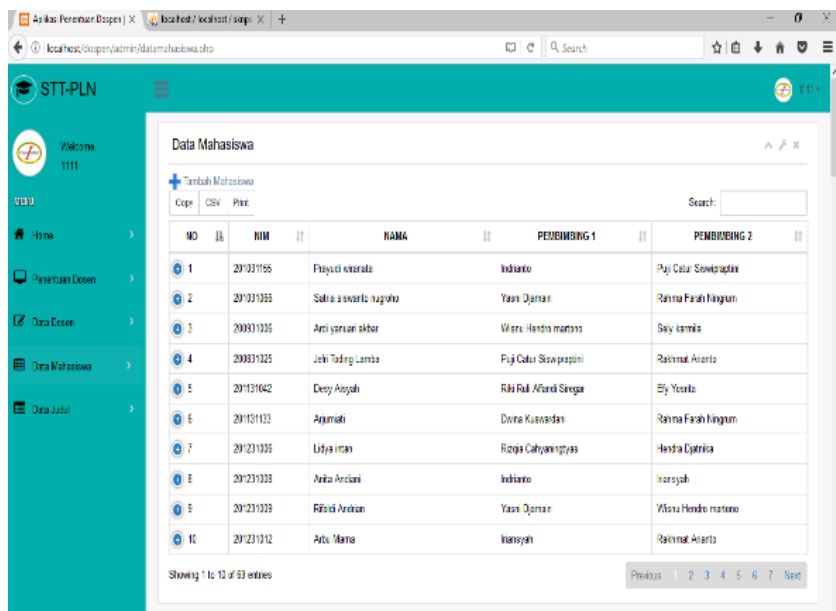

d. Halaman Data Judul

Gambar 10 Halaman Data Mahasiswa

Pada halaman data mahasiswa, terdapat tabel Informasi judul, dimana terdapat data nik, id judul judul dan action, data ini didapat dari hasil penginputan judul dan abstrak yang sudah dilakukan oleh mahasiswa. 


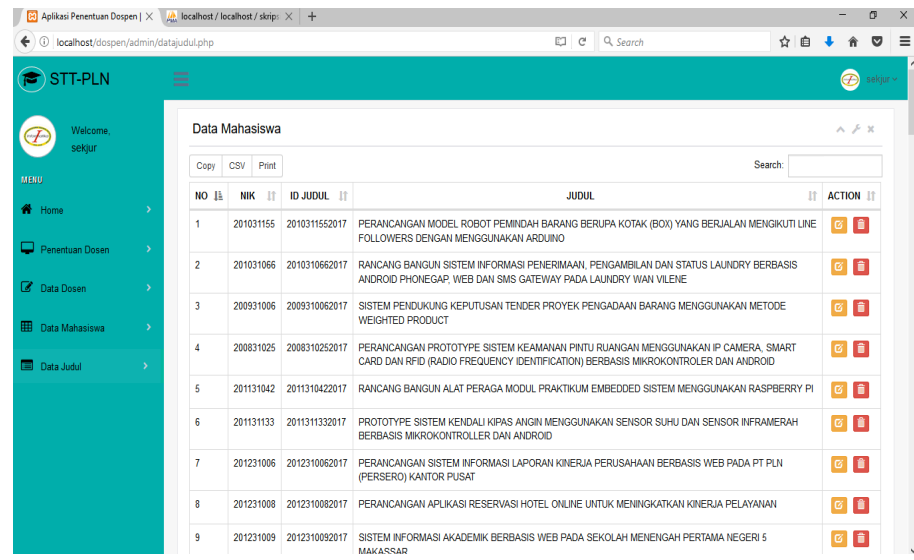

Gambar 11 Halaman data Judul

\section{Tampilan Menu Mahasiswa}

a. Halaman Utama Mahasiswa

Pada halaman utama menampilkan dua buah icon, dimana jika pada icon di click maka user akan masuk menampilkan form berdasarkan icon yang dipilih.

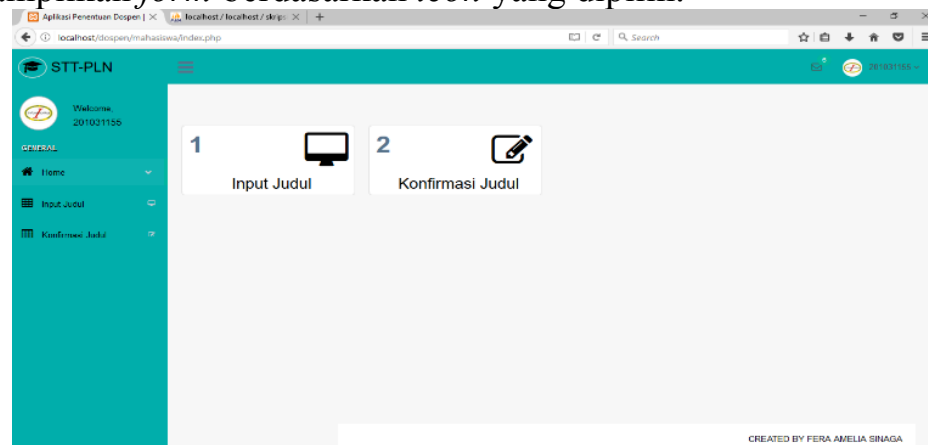

Gambar 12 Halaman Utama Mahasiswa

b. Halaman Input Judul

Pada halaman input judul, mahasiswa akan menginputkan data judul dan abstrak skripsi, yang nantinya akan diolah oleh system dengan metode TF-IDF dan VSM.

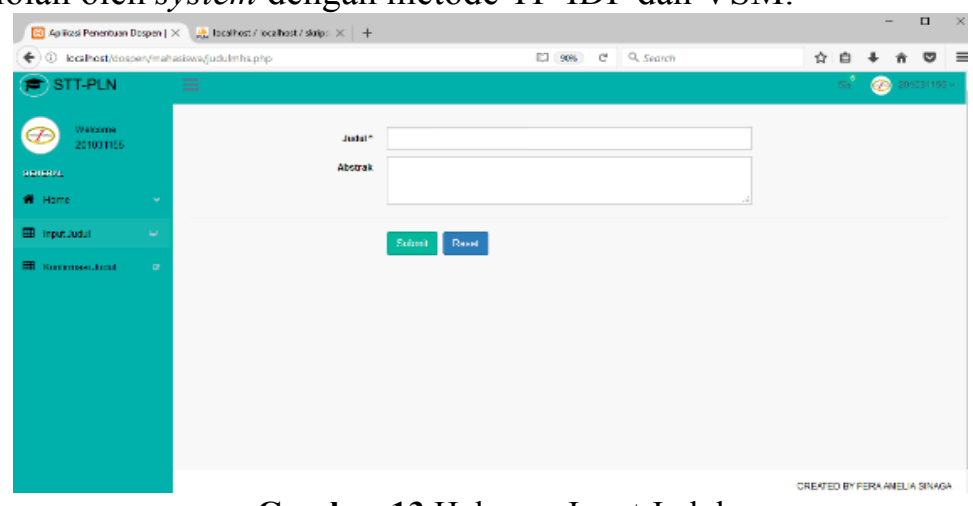

Gambar 13 Halaman Input Judul

c. Halaman Data Judul

Mahasiswa dapat melihat judul dan abstrak yang sudah diinputkan, dan mengedit judul dan abstrak jika ditemukan kesalahan, dapat dilihat seperti gambar dibawah ini: 
Computatio: Journal of Computer Science and Information Systems, volume 1, no 2, Oktober 2017

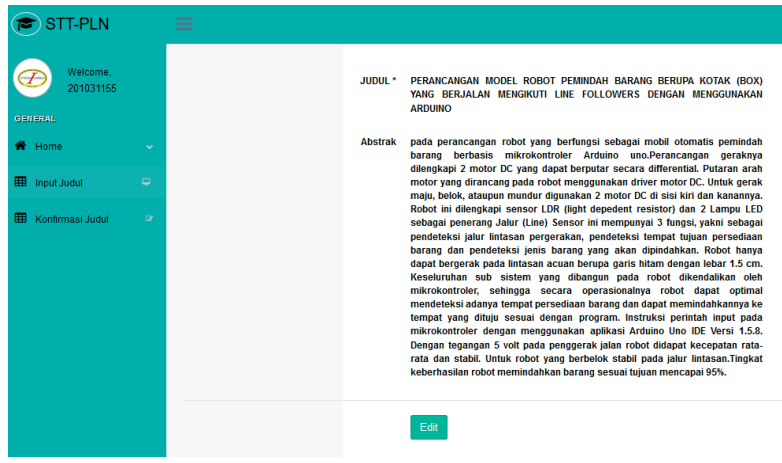

Gambar 14 View data judul dan abstrak

d. Halaman Konfirmasi

Pada halaman konfirmasi mahasiswa dapat melihat data dosen yang akan menguji siding skripsinya.

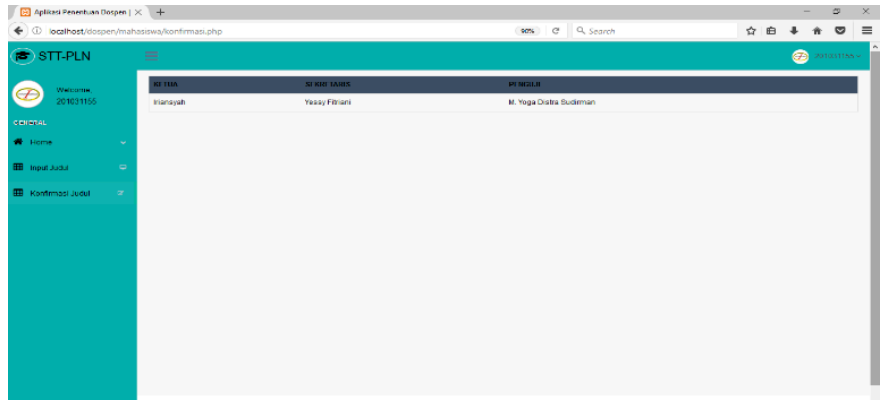

Gambar 15 Halaman Konfirmasi

\section{Tampilan Menu Dosen}

Pada penelitian ini, dosen hanya bisa melihat mahasiswa yang akan diuji, dapat dilihat seperti gambar dibawah ini:

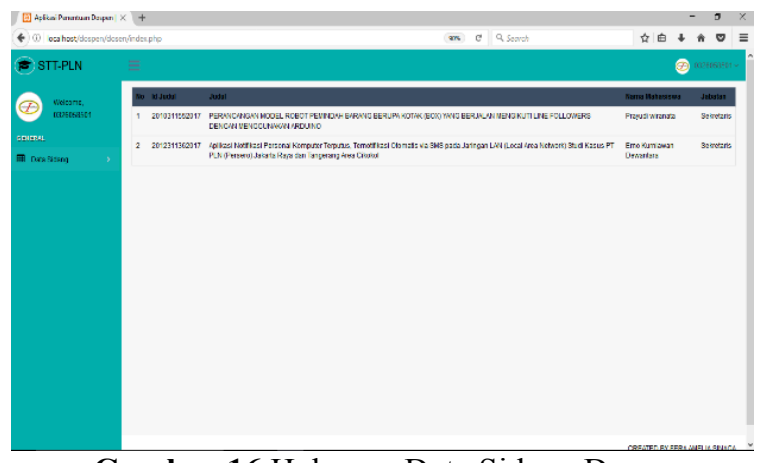

Gambar 16 Halaman Data Sidang Dosen

\subsection{Pembahasan}

Pengumpulan data dilakukan dengan mengambil skripsi mahasiswa Teknik Informatika STT-PLN di perpustakaan, dan wawancara. Wawancara dilakukan kepada sekretaris jurusan Teknik Informatika STT-PLN, dengan fokus terhadap sistem berjalan dengan penentuan jadwal sidang skripsi dan tim dosen penguji. Hasil dari wawancara bahwa proses pemilihan dosen penguji di jurusan teknik informatika masih secara subjektif, yaitu penentuan dosen penguji dipilih secara langsung oleh Sekretaris jurusan. Belum adanya sistem yang digunakan menjadikan tugas sekretaris jurusan dalam menentukan dosen penguji yang sesuai antara judul atau tema skripsi dengan konsentrasi dosen penguji menjadi tidak relevan dengan kompetensi yang dimiliki dosen penguji. Data set yang diperoleh akan dijadikan sebagai data training. Data- 
data tersebut dikumpulkan kemudian diolah menggunakan text preprocessing, Text preprocessing merupakan tahap proses awal terhadap dokumen skripsi untuk mempersiapkan dokumen menjadi dokumen yang akan diolah lebih lanjut. Tahapan text preprocessing yang dilakukan adalah tokenizing, filtering, stemming. Kemudian dokumen yang sudah diproses akan diberi bobot dengan menggunakan metode TF-IDF, setelah itu untuk menentukan klasifikasi dari dokumen skripsi digunakanlah metode Vector Space Model. Kemudian setelah didapat kan klasifikasi dokumen skripsi, akan dicocokan antara kompetensi dosen penguji dan klasfikasi dokumen skripsi. Terdapat tiga dosen penguji skripsi yang terbagi atas ketua, sekretaris dan penguji. Masing-masing posisi memiliki syarat-syarat yang berbeda. Ketua harus memiliki jabatan lektor kepala atau lektor, untuk sekretaris jabatan yang dimiliki dosen adalah asisten ahli sedangkan jabatan untuk anggota penguji bisa jabatan apa saja seperti lektor kepala, lektor, asisten ahli dan tenaga ahli.

Pada proses penentuan dosen penguji dilakukan dengan melakukan perhitungan menggunakan Microsoft excel dan kemudian membandingkan hasilnya dengan perhitungan yang telah dilakukan oleh sistem di aplikasi. Penentuan relevansi antara penentuan dosen penguji di uji dengan data testing dari 59 dokumen dan hasil klasifikasi yang didapat dari sistem, kemudian menghitung tingkat keakurasiannya, dimana diperoleh yaitu:

$$
\begin{aligned}
\text { Accuracy }= & \frac{\text { Jumlah Dokumen yang benar dikenali }}{\text { Jumlah Dokumen pengujian }} \times 100 \% \\
& =\frac{55}{59} \times 100 \% \\
& =\mathbf{9 3 , 2 2} \%
\end{aligned}
$$

Dari hasil pengujian, keakuratan terhadap kesesuaian kompetensi dosen penguji yang didapat oleh aplikasi ini mencapai 93,22\%. Dimana dengan jumlah pengujian 59 contoh data training, dengan tingkat error sebesar $6,78 \%$ terdapat 4 (empat) buah data training yang memiliki nilai belum tepat dalam penentuan kesesuaian kompetensi dosen penguji.

\section{PENUTUP}

\subsection{Kesimpulan}

Dari kesimpulan ini dapat disimpulkan bahwa :

1. Penentuan dosen penguji dapat dilakukan dengan menggunakan metode TF-IDF dan VSM, perhitungan data skripsi dilakukan dengan menggunakan Microsoft excel.

2. Penentuan dosen penguji skripsi dapat dilakukan berdasarkan kompetensi, dengan menerapkan metode TF-IDF dan VSM kedalam sistem

3. Dari hasil pengujian TF-IDF dan VSM dengan 59 data judul dapat merekomendasikan tiga dosen penguji skripsi, dengan syarat minimal satu orang memiliki kompetensi yang sama dengan topik skripsi dengan menghasilkan akurasi 93,22\%. 


\section{DAFTAR PUSTAKA}

[1] Gunawan, Lestari, I., \& Ihsan Zul, M. (2016). Sistem Pendukung Keputusan Pemilihan Pembimbing dan Penguji Proyek Akhir di Politeknik Caltex Riau. jurnal informatika.

[2] Nath Singh, J., \& Dwivedi, s. (2012). Analisi Vector Space Model pada Information Retrival. International Journal of Computer Applications, 14-18.

[3] Yuan, M., \& Xiong, Z. (2013). A Text Categorization Method using Extended Vector Space Model by Frequent Term Sets. Journal Of Information Science And Engineering 29, 99-114.

[4] Gawande, P., \& Suryawanshi, A. (2015 ). Improving Web Page Classification by Vector Space Model . International Journal of Innovative Research in Computer and Communication Engineering, 1252-1257.

[5] Wisnu, D., \& Hetami, A. (2015). Perancangan Informtaion Retreival (IR) untuk Pencarian Ide Pokok Teks Artikel Berbahasa Inggris dengan Pembobotan Vector Space Model. Jurnal Ilmiah Teknologi dan Informasi, Volume 9, Volume 9.

[6] Asshidiq, A. S., \& Sulistyo, M. (2013). Penilaian Ujian Bertipe Essay Menggunakan Metode Text Similarity. Jurnal Informatika.

[7] Aziz, A. S., \& P.S, K. (2015). Implementasi Vector Space Model dalam Pembangkitan Frequently Asked Questions dan Solusi yang Relevan Keluhan Pelanggan. Scientific Journal Informatics, 2.

[8] Lestari, K. (2013). Query Expansion pada Sistem Temu Kembali Informasi dengan Model Ruang Vektor. Naskah Tugas Akhir, 24.

[9] Pardede, J., Barmawi, M. M., \& Pramono, W. D. (2013). Implementasi Metode Generalized Vector Space Model pada Aplikasi Information Retrieval. Jurnal Infromatika No.1, Vol. 4, Januari-April, ISSN : 2087-5266, 35

[10] Herman, Achmad, A., \& Ahmad, a. i. (2014). Klasifikasi Dokumen Naskah Dinas Menggunakan Algoritma Term Frequency - Inversed Document Frequency Dan Vector Space Model.

[11] Imbar, R. V., Adelia, Ayub, M., \& Rehatta, A. (2014). Implementasi Cosine Similarity dan Algoritma Smith-Waterman untuk Mendeteksi Kemiripan Teks. Jurnal Informatika, Vol. 10 No. $1,31-42$.

[12] Amburika, B., Herry, Y. C., \& Uriawan, W. (2016). Teknik Vector Space Model (VSM) Dalam Penentuan Penanganan Dampak Game Online Pada Anak. jurnal informatika, 7338.

[13] Arief, M. R. (2011). Pemrograman Web Dinamis Menggunakan PHP dan MySQL. Yogyakarta: ANDI OFFSET. 